\title{
Article
}

\section{The kingdom of the shore: achievement of good ecological potential in reservoirs}

\author{
Brian Moss \\ School of Biological Sciences, University of Liverpool, L69 3GS, UK. Email:brmoss@liverpool.ac.uk
}

Received 24 April 2007; accepted 24 September 2007; published 23 January 2008

\section{Abstract}

The European Water Framework Directive requires member states to restore aquatic habitats to good ecological status (quality) by 2015. Good ecological status is defined as slightly different from high status, which, according to the Directive, means negligible human influence. This poses problems enough for restoration of natural habitats but artificial reservoirs are not excluded from the Directive. They must be restored to good ecological potential. The meaning of good ecological status is linked to that of 'high' ecological status, the pristine reference condition for aquatic habitats under the Directive. From the point of view of an ecologist, this is taken to mean the presence of four fundamental characteristics: nutrient parsimony, characteristic biological and physical structure, connectivity within a wider system and adequate size to give resilience of the biological communities to environmental change. These characteristics are strongly interrelated. Ecological potential must bear some relationship to ecological status but since the reference state for ecological quality is near absence of human impact, it is difficult to see how the criteria for ecological status can be applied to a completely man-made entity where the purpose of the dam is deliberately to interfere with the natural characteristics of a river or former natural lake. Reservoirs are disabled lakes, usually lacking the diversity and function provided by a littoral zone. Nonetheless, pragmatic approaches to increasing the biodiversity of reservoirs are reviewed and conclusions drawn as to the likely effectiveness of the legislation.

Keywords: Dams; Water Framework Directive.

\section{Introduction: an ambiguous status}

By the Green River, in Dinosaur National Monument in the United States of America, is an information board erected by the United Sates National Parks Service. It says:

'Born a small stream in north-western Wyoming and raised by glaciers and lakes of the Wind River mountain range, it (the Green River) is the largest tributary to the Colorado
River. John Wesley Powell, a one-armed veteran of the Battle of Shiloh, was the first successful challenger to the Green River in 1869. His adventure led to the naming of Disaster Falls, Hells Half Mile, Whirlpool Canyon and Split Mountain Gorge, all within Dinosaur National Monument. Now controlled by the Flaming Gorge Dam one hundred miles to the north, the Green River will never again equal the fury Powell knew'. It is a politically clever, ambiguous statement that can be 
taken either as condemnation or praise for a dam that has nonetheless caused deleterious effects (Andrews, 1986).

Reservoirs are controversial structures. On the one hand, we need them; water does not fall evenly throughout the year in many regions and must be stored for domestic supply. Natural lakes can do this but they are not always placed for our convenience. Rivers can supply water but they tend to become contaminated by human activities and agriculture and have little storage capacity. Storage in a reservoir alleviates some of these problems. Storage is also necessary to support agriculture. Food has to be grown and some irrigation is necessary even in moderately dry regions. Further, especially now that it is accepted that fossil fuel burning has caused us climate change, energy generated from other sources must become more important and hydroelectric dams are of proven value.

On the other hand, covetous lobbies have perhaps pushed the construction of dams, when and where and of a size, that were inappropriate. The World Commission on Dams (2000) found many instances where performance fell greatly short of promise and the human and ecological problems caused by dam construction are legion. Former crucial and productive floodplains, their fisheries and traditional agriculture, have been lost; millions of people have been displaced to less equable lives; and the passage of migratory fish has been impeded. Some rivers resemble staircases of lakes, so many dams cross their flow that historic runs of fish are long gone. Other major rivers no longer reach the sea for their waters are taken by irrigation dams eventually to evaporate in deserts whose soils become saline and sterile after a time.

In our aspirations for more wealth, control and power, ecosystems that had been tested, by the continual action of natural selection and geomorphological equilibrium, to near perfection for purpose, have been ruined, the goods and services they once provided ignored and devalued. But we have made our bed and no matter how lumpy and uncomfortable it will increasingly become, we must lie in it. Some smaller dams, perhaps 500 of them, that are no longer needed, for example for driving grist mills or floating timber, have been removed in North America, with manifest ecological benefits (Bednarck; 2001, Johnson \&
Graber, 2002), though the number is small compared with estimates of up to 2.5 million such structures in the USA alone. The bigger reservoirs, with dams more than $15 \mathrm{~m}$ high, perhaps forty thousand of them on a world basis, for the most part are here to stay in the conceivable future. We must make the best of them though to many eyes they may often not be attractive features of the landscape (Fig. 1).

\section{The Water Framework Directive}

In Europe, the Water Framework Directive (European Commission, 2000) has given the impetus to soften the harsh effects of the concrete walls and sterile shorelines that epitomise many reservoirs. The Directive has many provisions, key ones being that aquatic systems must be managed as river basin districts, a re-iteration of the scientific truism that the catchment, not the body of water, is the fundamental unit of freshwater (and coastal marine) ecology; that water must be realistically priced and no longer abused as a free good; and that aquatic habitats must be restored to 'good ecological status' by 2015, following an assessment of their current quality on a five-point scale from 'high' to 'bad'. 'High ecological status is defined by the pristine state or, at most, with negligible human influence, whilst good quality is defined as only slightly different from high. Clearly

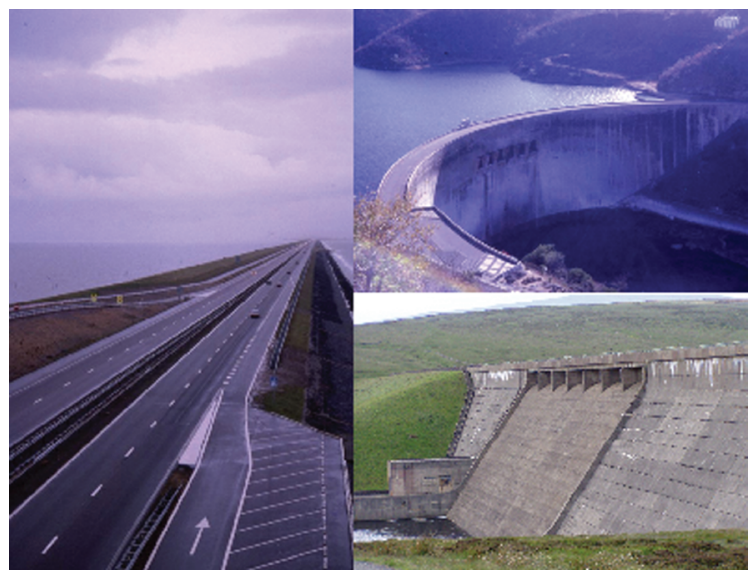

Fig. 1. The concrete dams that contain many reservoirs epitomise the problems of increasing their ecological value. Left, the dam across the Zuider Zee, Netherlands. Right upper, the Kariba Dam, Zimbabwe. Right lower, the Cow Green Dam, UK. 
there is no such thing as a reservoir of high ecological quality; they are, after all, created by human activity. But reservoirs are not exempt from the Directive. They are required to meet 'good ecological potential' by 2015 .

In many cases reservoirs may be derogated from the provisions of the Directive, provided reasons can be given to the European Union that alteration of their structure or management will be too expensive or not in the public interest, but societies function best when they adhere to the spirit of their considered legislation and this means an honest attempt to improve the ecological quality of reservoirs. Though the competent authorities, the government agencies responsible for operation of the Directive, have not yet taken an explicit view (Moss, 2007), professional ecologists will have little problem in determining what high and therefore good, ecological quality means in general. There has been substantial research on near-pristine systems in other parts of the north-temperate world as a guide, even if palaeolimnological studies have shown that many such systems have been progressively altered in much of Europe since the Bronze Age. What 'good ecological potential' for reservoirs might mean, however, is another matter. It must nonetheless be somehow linked to what is meant by good ecological quality for natural lakes.

\section{Good ecological quality}

Understanding ecological quality emerges from G.E. Hutchinson's (1965) concept of 'the ecological theatre and the evolutionary play', and an appreciation of pristine systems, which are the reference standards for the Water Framework Directive. The first consideration is that such systems are always adjusting, through natural selection of individual genotypes and competition among species, to the continuously changing conditions at any particular place on the Earth's surface. Natural directional change and superimposed fluctuations are normal and the physico-chemical conditions and community compositions will reflect this with continuous mutual adjustment. High ecological quality is thus specified neither by a particular set of concentrations of substances nor a prescribed list of species. The continual operation of competition and predation among organisms that compete for resources such as food and space means also that there is only a tenuous and very general relationship between the abundance of any particular species and physico-chemical characteristics of the habitat. The drafters of the Water Framework Directive have ignored this change in emphasis from the simple environmental determinism of the midtwentieth century to the much more dynamic concepts of the twenty-first. There seems to be a presumption that high quality can be written down as a set of concentrations and a list of species and that lesser qualities can be expressed on simple linear scales of increasing concentration and decreasing abundance such that the ratio of present value to reference value gives a simple ecological quality ratio or index (called EQI in the Directive). It seems, however, highly unlikely that such an index has any accuracy.

Pristine (high) ecological status is a much more sophisticated concept but can be summed up in four generalities: parsimony of nutrient availability; characteristic physical and biological structure; connectivity and exchange of materials and organisms with other systems; and sufficiency of size to maintain internal mechanisms for resilience to change rather than dependence on externally imposed management. High quality systems are self-contained and that also poses a problem in defining ecological potential for humanconstructed reservoirs: there is no possible reference standard. But there can be some extensions in thinking.

\section{Nutrient parsimony}

The importance of nutrient parsimony is easy to grasp. Biodiversity and nutrient availability are inversely related within most ecosystem types. Nitrogen, because its compounds are so reactive, tends to accumulate in the atmosphere where it is relatively unavailable except to nitrogen-fixing prokaryotes, and phosphorus, through the accident of the composition of the material that condensed to form the Earth, is scarce relative to its needs by organisms. Nonetheless all organisms require plentiful supplies of these elements with the result that mechanisms 
have evolved to retain them within biological systems. Where fresh water is abundant, undisturbed catchments tend to be forested. Trees retain $\mathrm{N}$ and $\mathrm{P}$ by translocation into the biomass at the end of the growth season and scavenge available $\mathrm{N}$ and $\mathrm{P}$ from the soil by very efficient mycorrhizal systems. Not surprisingly, the waters that run into streams from undisturbed catchments have so little $\mathrm{N}$ and $\mathrm{P}$ that available forms of their compounds may be almost indetectable. As a rule of thumb, less than $5 \mu \mathrm{g}$ total $\mathrm{P} \mathrm{L}^{-1}$ and $100 \mu \mathrm{g}$ total $\mathrm{N} \mathrm{L}^{-1}$ are probably typical even for easily weatherable catchments. Pristine stream systems have evolved intricate mechanisms for importing these nutrients from distant sinks like the ocean, involving interactions of salmonids, bears and timber (Krokhin, 1975; Cederholm et al., 1999), a manifestation also of the connectivity that characterises high quality systems. Waters draining from catchments disturbed by agriculture and settlement will have concentrations orders of magnitude more than those naturally found.

\section{Structure}

Characteristic structure, the second key feature of high quality ecosystems, is also easily understandable in the Hutchinsonian context. Organisms respond to the nature of the environmental theatre and simultaneously create part of it by their existence and activities. A pristine river will often be overhung by forest or scrub in its headwaters, will naturally occupy a wider bed in the wetter season, and will retreat to a smaller channel in the drier. Woody debris may sometimes obscure its course; leaf packs will form behind the debris and provide habitat and energy for the animal community. Lakes will reflect the morphology of their basins by the relative abundance of plant-dominated communities in shallow and sheltered parts and microbe-dominated planktonic communities in deeper, more turbulent areas.

Food webs also are part of the structure and indeed may maintain it. In the north-temperate region, predation is central to the stability of plant-dominated communities through trophic cascades that help maintain severe grazing by zooplankters on algae (Carpenter et al., 1985; Findlay et al., 2005). Carnivory, through wolves, completely alters the vegetative structure of upland streams by changing the habits of grazing deer (Ripple \& Beschta, 2004a, b; Beschta \& Ripple, 2006). Brown bears influence the nature of the riparian habitat, the provision of woody debris and the sustained recruitment of salmon (Calman et al., 2002; Helfield \& Naiman, 2006). Deeper water refuge areas in sub-tropical north American swamps are maintained in the dry season for a host of reptiles, amphibians and birds by alligators digging holes (Davis \& Ogden, 1994) and the complexity of habitat of tropical swamps is maintained by the movements of hippopotami (McCarthy et al., 1998).

There appear to be distinctive patterns within food webs that maintain their stability to imposed change (Warren, 1994). There are also differences in the open waters of warmer regions from the better-known cool systems (Meerhoff et al., 2007). In warm waters, more species of fish that are omnivorous and rapidly reproducing intensify the predation of both planktonic and plant-associated invertebrates and increase the potential for cyanophyte blooms and the sensitivity of the systems to nutrient supply. Floating plant dominanceover submerged communities may reflect this risk and the greater variation between years in water levels of warm lakes. Fluctuating level is often lethal for substratum-rooted plants, but not for floaters that dangle their roots in the water.

\section{Connectivity and resilience}

The third characteristic, connectivity, is embraced by the first two to some extent, for no system exists stably on its own. Ecosystems decline when they are isolated. For aquatic systems water flow is clearly essential, so there is adjustment of growth and life history to hydrological patterns in pristine systems (Hynes, 1979). Links among catchments, riparian zones, rivers, floodplains, the ocean and atmosphere are sine qua non for a stable system. Nature reserves that are fenced, either physically or through isolation among alien systems of agriculture, tend to decline in diversity, for immigration is impeded whilst loss through chance local extinction is inevitable. Their usually small size, itself a manifestation of lack of 
connectivity, means that food webs are incomplete. A lack of top predators allows the herbivores to consume much of the plant diversity (Terborgh et al., 2001, 2006).

The need for resilience is because systems must be big enough to allow internal repopulation after natural disturbances. Flood, fire and drought will devastate a small system but be accommodated in a large one. It is the contrast between the house of the little pigs that the wolf easily blew down, and the towers, barbicans and battlements of the mediaeval castle before the age of gunpowder. None of these four characteristics, nutrient parsimony, structure, connectivity and resilience, however, is separate from the others. They are all manifestations that allow a self-functioning system to persist despite continued environmental change. Such systems are self-regulating without any help from human hand; they are the ultimate manifestations of sustainability; they cannot be improved by anything we do for they are continually subject to the much more ruthless quality control of natural selection.

\section{Good ecological potential in reservoirs}

Where then does this leave the concept of ecological quality for reservoirs? Clearly they can never attain the self-regulation of natural systems. They are built to upset that very self-regulation to serve purely human purposes, and since the characteristics of nutrient parsimony, characteristic structure, connectivity and resilience are all manifestations of the same integrity, it can be argued that the achievement of high potential is conceptually nonsense.

We have then to be pragmatic. If the four characteristics, by an abandonment of logic in the service of practicality, can be considered separately, to what extent can they be achieved in a managed system? What can an approach simply of attempting to attain greatest biodiversity (in all the senses of habitat, species and genetic diversity) achieve? Biodiversity is not an absolute measure of anything, of course. The sparse tundras contribute no less to the functioning of the biosphere than the rich coral reefs, deep ocean and rain forests, but within a given regime, it will probably be agreed that increasing the local biodiversity, in a way that can be self-maintaining, represents some improvement in ecological potential. Possibly it is only for such artificial systems as reservoirs that the present approach of environmental determinism being taken by the competent authorities attempting to deliver the provisions of the Water Framework Directive has any relevance.

There will be little argument over targets for parsimony of nutrient loading. Reservoirs built for water supply are often close to farmed and developed areas and thus are among the most problematic of lakes where algal growths and algal toxins are concerned. Directly or indirectly, algae and nutrients go hand in hand. There are no particular techniques that apply to reservoirs that do not apply to natural lakes and the available approaches to nutrient control are well known (e.g. Cooke et al., 2004) and do not require further review here.

There are some specific issues though. In the past, the surroundings of reservoirs have often been planted with exotic conifers for reasons of reducing evaporation, maximising financial returns on catchment land owned by the reservoir operators or minimising erosion. Forestry operations however are not necessarily beneficial to water quality, especially during felling and replanting. As a general rule, progressive reconversion of plantations to native forest, or appropriate native vegetation in arid areas, is the best remedial option. And there is one counter-aspect that merits comment. The very placing of dams on river systems blocks movements of migratory fish. Migratory fish bring nutrients in their bodies and eventual carcasses that appear to be essential for the ecological functioning of headwater streams that include their spawning sites (Helfield \& Naiman, 2006). Lack of salmon runs has led to an artificial oligotrophication of sites in north-western North America and possibly elsewhere. Parsimony of nutrient flow does not mean absence of nutrient flow. Fertilisation has been found necessary in some North American reservoirs to maintain fish production that had previously been maintained by migratory fish (Perrin et al., 2006). 


\section{Structure, and the importance of the littoral zone}

It is in structure and connectivity, however, that the biggest problems arise in increasing the ecological potential of reservoirs. Reservoirs are disabled lakes. They are like a limbless person with a malfunctioning bladder that is controlled by the whim of a cavalier physician. In particular, many reservoirs lack the littoral zone that is crucial to the maintenance of lake biodiversity and they lack the characteristic rhythmic pulse of seasonal inflow and outflow of water otherwise guaranteed by climate.

The lack of the littoral zone is a major issue for restoration of good ecological potential to reservoirs. The littoral zone is defined as that part of a lake where photosynthesis-based growth is possible on the bottom of the lake by algae or larger plants (Fig. 2). It extends down the bottom profile to the point where insufficient light penetrates to support net growth and it includes the water column above the bottom. Its extent will vary seasonally because of changes in light penetration through the water column caused by changes in phytoplankton crop or the colour of incoming water and it includes the swampy regions at the margin where the characteristic plants will be emergents like reeds (Phragmites spp.), papyrus

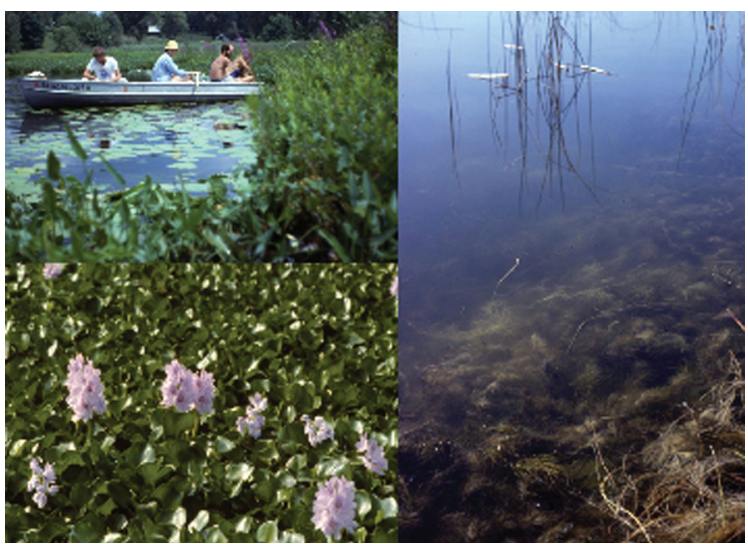

Fig. 2. The littoral zones of natural lakes are major sources of biodiversity (upper left), provided by a higher plant or (right) even by filamentous algae. In reservoirs, littoral zones are often poorly represented, but even problematic weeds like introduced floating species (e.g. water hyacinth, lower left) may provide some structure for non-planktonic organisms.
(Cyperus papyrus), alder (Alnus spp.), willow (Salix spp.) or swamp cypress (Taxodium distichum). All of a very shallow lake may be littoral but only a small proportion of a deep one in a steep-sided basin. Nonetheless, even an aerially proportionately small littoral zone may be of great importance to the lake system as it contains greater biodiversity and much more structure than the pelagial. Pelagial and littoral are linked to each other and also to the catchment. The littoral zone is the pivot between pelagic and catchment, and thus merits a particular importance.

The history of limnology, however, has largely been the history of planktonology and pelagic fisheries and the littoral has been comparatively neglected. Open water was easy to sample and study. Wind mixes it to comparative uniformity; electromagnetic radiation imposed the order of vertical stratification on it. A net or bottle was sufficient for sampling and only a moderate amount of ingenuity was needed to sample discretely at different depths. The chemistry was comparatively simple, at least until the interactions at the sediment surface were realised. Because of the shoaling nature of pelagic fish, commercial freshwater fisheries were open water fisheries and this too drove a dominance of studies of the open water.

\section{Littoral ecology}

The littoral zone, with frequent disturbance from changing water levels and freezing at the edge is at once more complex and epitomises the freshwater biota. Because water has freezing and melting points close to the mean temperature of the Earth's surface, it is very vulnerable to changes in state. Likewise, because freshwater basins are geomorphic features that have been often disrupted by geological and climatic events, freshwater organisms, through natural selection, have become well adapted to the quasi-disasters of freezing, flooding, desiccation and destruction. In contrast to their marine equivalents, many freshwater invertebrates and algae have resting stages; some fish can breathe atmospheric oxygen; and aquatic plants are adept at vegetative reproduction from dislodged fragments as well as seeds. The littoral contains organisms, for example emergent vascular plants 
(Hutchinson, 1975), migratory mammals like the sitatunga, hippopotamus and otter, reptiles such as anacondas and crocodilians, and water birds, that are essentially terrestrial in their physiologies, but to greater or lesser extents exploit the resources of fresh water. It contains organisms that cannot survive complete drying out, yet still retain features of their terrestrial origin, like the submerged plants and many insects. The submerged plants usually have aerial flowers and are mostly pollinated by terrestrial agents like wind and insects rather than water; some, like the isoetids and littorellids, are still highly cuticularised. The aquatic insects are often aquatic in their juvenile stages but aerial as adults. And the littoral zone also contains organisms that are obligately aquatic, like most fish and invertebrates other than insects. It is from this multifarious group that the pelagic biota has secondarily evolved.

This pelagic biota, in contrast, is a very specialist group of organisms, highly adapted to an unusual habitat, rather than the mainline community that it is usually assumed to be. Its algae, like its zooplankters, place more emphasis on asexual than sexual reproduction, perhaps because contact between individuals, in a medium in which relative spacing is very large, is infrequent. Most pelagic organisms are small, for nutrient availability is naturally low and the risks of sinking, washout, and grazing or predation, in a medium where there is no cover or refuge, place emphasis on rapid reproduction to meet inevitable large losses. Even for fishes, the medium favours $r$ selection but there are few freshwater fish that rely on pelagic eggs. Most return to the safety of the littoral to spawn.

A number of simple concepts explain a great deal of behaviour in the pelagial: nutrient limitation and its links with algal population dynamics (Lund, 1964); sizeselective-predation among the zooplankters (Hrbacek et al., 1961); simple top down interactions from the piscivorous fish to the zooplankton and sometimes down to the nutrient chemistry (Moss et al., 2004). Such simplicity is absent from the littoral. The structure given by the submerged plants creates much greater biological complexity and the outcome of a particular environmental change is much less easily predictable. There are many mathematical models for the pelagic, but few for the littoral.
Even the water chemistry in the littoral has a strong spatial pattern that may change considerably in a few hours as a result of metabolic activity of the plants (Barker, 2006).

Sampling the biology of a littoral zone will reveal a set of very heterogeneous patterns (Jeppesen et al., 1998). There are shoals of zooplankters, a complex assemblage of grazers, some associated with plant surfaces, others clinging to the edges of plant beds and drifting out into the open water to graze at night (Timms \& Moss, 1984). Movements of fish between plant beds and the open water optimise the balance between food availability and vulnerability to predators. The plant surfaces are chemically complex. Periphyton communities are complex micro forests of algae, protozoa, bacteria and inorganic and organic debris (Moss, 1995). pH values may vary by two or three units within a distance of only a millimetre or two from the leaf surface (Jones et al., 2000). Sometimes the littoral will provide organisms to the pelagic through emergence of algae from resting spores (Hansson, 1996) or horizontally migrating zooplankters and fish. Influences on the pelagial may come even through allelopathy, the production of substances that inhibit phytoplankton growth (Van Donk, 2005).

Lakes have traditionally been regarded as autotrophic systems. Photosynthesis by algae and plants within the system was presumed to provide all the energy required by the food webs. Hints that this might not be the case, and that there might need to be supplementation by organic matter coming from outside the lake, have been present for some time. Extensive work, including characterisation by stable isotopes, suggests an import of organic matter (Cole et al., 1994; del Giorgio \& Peters, 1994; del Giorgio et al., 1997; Jonsson et al., 2001; Hanson et al., 2004). Whether this organic matter is derived from the fringing submerged littoral community, the emergent littoral community or the terrestrial vegetation of the catchment is not yet clear. Probably all three contribute but it seems likely that the littoral communities, on the grounds of simple proximity, contribute most, through secretion or decomposition, to form soluble organic matter. The issue is partly semantic. It depends on what is considered to be 'the lake'. 
Traditionalists who see the pelagic as the really important part of the lake might have to conclude that the 'lake' is a heterotrophic system. Those that include the littoral, including the surrounding wetland swamps (sometimes regarded as a separate 'terrestrial' system for reasons that bear no logic) might find the lake autotrophic once the huge contribution of the emergent plants is included, including the cycling through the atmosphere and back to the water of their released oxygen. Only if this contribution still leaves the system requiring organic matter from elsewhere could the lake be considered truly heterotrophic. What has been seen as a new paradigm (O'Sullivan \& Reynolds, 2003) may merely be an extension of the limited classical view of the primacy of the pelagial. Upstream temperate rivers are clearly heterotrophic as they depend on leaf material washed in during the autumn (Harmon et al., 1986). But since the real unit of limnology is the catchment, the system must ultimately be autotrophic and the controversy that is raging over this issue may ultimately depend on the boundaries of subject rivalries.

In summary, the importance of the littoral zone lies: in its much greater biodiversity compared with the plankton system, in all components from microorganisms to fish, birds and mammals; in its greater production per unit area and potential supply of material to support the open water system; in its provision of refuges against predators, spawning sites, and nursery and feeding sites for open water fish; and for its supply of food for amphibious and terrestrial animals moving into its outer fringes seasonally or daily. It is also a major provider of fish, building materials and sometimes medicinal plants for traditional peoples living by the lake. In a reservoir, most of these resources are absent.

Reservoirs lack littorals for several reasons. Dams tend to be built in places where the least length of dam holds the maximum amount of water. The ideal is a steep-sided, deep, narrow gorge. The steepness of the basin means that shallow water is limited. Secondly, what littoral there might be is unpredictably disturbed by non-seasonal or extreme or irregular changes in water level in response to hydroelectric or supply needs. The potential littoral zone may be sterilised for a season by a short drying out and many reservoirs in summer have unsightly bare margins (Fig. 3) where aquatic plants are eliminated by drying and terrestrial ones by subsequent equally unpredictable flooding (Furey et al., 2004). Such drying may preclude fish spawning and result in low fish recruitment, itself leading to reduced zooplanktivory, enhanced zooplankton grazing and clearer water in the pelagial than might be expected from the availability of nutrients (Duncan, 1990). It also results in reduced fishery potential. Alternatively it may reduce production because of destruction of plant communities at the edge and loss of the migration interactions and supply of organic matter that these would otherwise provide.

\section{The importance of connectivity}

The second major problem in restoring good ecological potential to reservoirs is in resuming connectivity. Connectivity is inevitable in pristine aquatic systems and is the essence of the global hydrosphere. Water moves from the atmosphere to the catchment, streams, rivers, lakes and eventually to the estuaries and ocean. The systems have adjusted over time both biologically and geomorphologically to the flows received, including not just the average but also the extremes. Pristine freshwater systems are nonplussed by flood or drought. A reservoir alters the mean flow, if water is diverted or evaporates

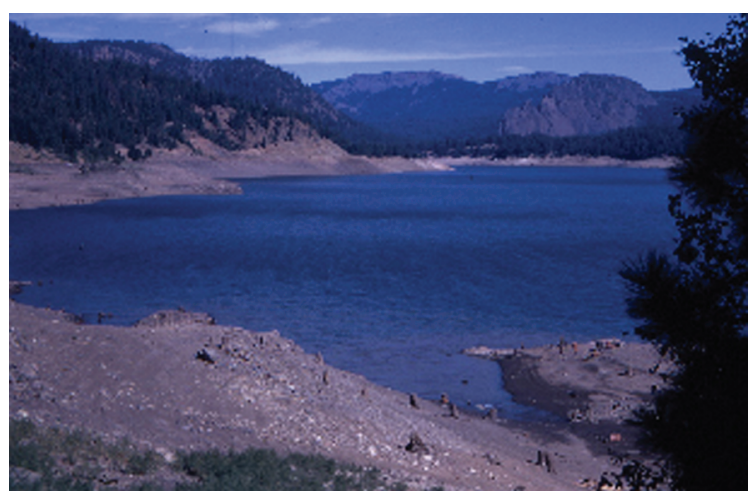

Fig. 3. Reservoirs are disabled lakes. One aspect of their disability is the lack of a littoral zone because unnatural fluctuations in water level result in a sterile shoreline, sometimes dry, sometimes flooded but with no predictable pattern to which organisms can adjust. 
from it, but particularly pushes the extremes beyond the evolutionary experience of the system. All sorts of ecological phenomena, from the balance of feeding guilds of invertebrates to the ability of migratory fish to reach their spawning grounds, are altered (Baxter, 1977; Ligon et al., 1995; Petts, 1980; Power et al., 1996; World Commission on Dams, 2000). Water temperature may fluctuate wildly from previous patterns as water is released erratically from the hypolimnion or epilimnion in summer and this will destroy fine linkages between life histories and food availability for animals. Downstream habitats dependent on seasonal floods may not receive them or experience them at periods of previous low water when nesting birds may be washed out (Davis \& Ogden, 1994). A single dam, if it disconnects the upstream river from the downstream for migratory fish may influence the entire course of a river. Because they are very disturbed habitats, however, reservoirs may also facilitate spread of invasive species (which are favoured by disturbance) across landscapes. They appear to have aided the spread of zooplankton species, particularly of the tropical Daphnia lumholtzii and the brackish Eurytemora affinis across the United States (Havel et al., 2005). The presence of invasive species must be seen as detrimental to ecological quality in natural lakes, though in the sparsely diverse environments of many reservoirs, they may have local merit. This cannot be assumed, however.

\section{Mitigation to achieve good ecological potential in reservoirs}

Currently, there is a vacuum of thinking as to how good ecological quality, in the sense of the Water Framework Directive, will be achieved in natural lakes (Moss, 2007) and the efforts of governments and their agencies appear to be devoted to developing indices and measures without much concept of scenarios of what ecological quality actually means. Indications are that ecological quality is being seen rather superficially as a set of chemical concentrations to which a set of biological indices will be matched, and that the profounder concepts have been ignored. Little may thus ultimately be achieved in terms of restoration of ecological functioning. Habitats will have been moved up a league table defined by convenience. Boxes will have been ticked, but the Earth's ecological systems will not have much benefited.

This approach leaves reservoirs very much as Cinderellas. They will be the last to be considered and many will be derogated from consideration on grounds that they are highly modified habitats about which not much can be done. There is truth in that. To do much would be like contemplating the return of the City of London to a floodplain oak/alder woodland. But there may be mitigations that can increase the local biodiversity a little in a cosmetic way.

Nutrient parsimony offers no conceptual problems. Reservoir managers will seize on nutrient control measures as avidly as conservationists and indeed there is good understanding (Reynolds et al., 1984) of how to manipulate management regimes to minimise algal bloom problems and good models to predict behaviour of the phytoplankton community (Lewis et al., 2002). Water quality from the point of view of reservoir operators is not, however, quite the same as ecological quality. In the cases of reservoirs where oligotrophication owing to the blocking of runs of salmonids has been a problem, fertilisation has been used to restore previous fish production if not previous fish communities (Perrin et al., 2006). Often the motives have been for provision of fisheries for recreational angling rather than ecological integrity, however, and it may be that reservoirs have often been over-fertilised compared with the previous nutrient state of the river in the interests of promoting sport fishing.

The presence of plants is as closely associated with increased biodiversity of animals in reservoirs as it is in natural lakes (Cronin et al., 2006) and so rehabilitation of productivity and biodiversity has been attempted, again in the interests mostly of angling, by provision of structures at the edges (Prince \& Maugham, 1978; Brown, 1986; Bolding et al., 2004; Wills et al., 2004; Roni et al., 2005). Sometimes plastic crates, old tyres, concrete slabs or pipes or woody structures like brushwood bundles, stakes or logs have been used and sometimes tolerant plants, such as the water willow, Justicia americana, have been planted 
(Strakosh et al., 2005). The latter will stand up to four weeks of flooding and eight of drought so can be used if a suitable regime is maintained. The general conclusion is that natural materials are cheaper and that such structures lead to greater fish densities. However, the mechanism appears to be a concentration of open water fish into refuges against predation or high irradiance rather than an increase in absolute production. Since fishermen catch more when the fish are concentrated, there are fears that overfishing might be encouraged by such practices. A better option could be to re-form shallows at the edges by earth-moving or back fill but this might be expensive and might be temporary as currents and wave action move the new material down the slope of the reservoir bed and reinstate whatever equilibrium bed-form can coexist with them. Alteration of the water regime would be necessary, not only to keep a littoral zone under water for the whole of the growing season at least, but simply to maintain the new sediments in position under the shallow water. Underwater barriers to fence in the sediment could prevent its erosion but maintenance of a high water level is an absolute need if the littoral is not just to be of emergent plants like reeds that can tolerate some drying. Such a habitat might provide some niches for birds and has been used in Japanese and Chinese reservoirs to increase food fish production (personal observations) and in the lakes around the IJsselmeer in the Netherlands.

Part of the essence of structure is also in food webs so perhaps there is more scope for restoration there. Many reservoirs have been stocked with fish for angling but high ecological potential must include some concept of selfsustainability. Most freshwater fish, in contrast to oceanic ones, are not open-water spawners casting their eggs freely into the plankton community. Freshwater species usually lay their eggs on substrata, either rocks, sand, plants or debris and this must obviously be kept wet. There is scope for water level management to keep levels high in spring to allow for spawning and an occasional omission to do this because of operational needs can be tolerated by many fish species. Large changes in recruitment from year to year in response to spring weather and water temperature are usual. Ecological potential can be gained by avoiding also the stocking of alien species. Accidental invasions are another matter and many reservoirs have suffered large problems, particularly with floating plants that come to dominate because they can tolerate changes in water level better than rooted ones. There is an argument for tolerating such plants in that they create some habitat structure for invertebrates and cover for fish, providing nutrient parsimony can be achieved. Floating plants, like phytoplankton, are dependent on dissolved nutrients and there is a close link between extent of floating weed problems and nutrient loading.

Migratory fish have always figured in considerations of reservoir use and there is a large experience in the design of fish ladders to allow the fish to negotiate the dam (World Commission on Dams, 2000). Not all work well, however, for it may be difficult to get the fish to enter them and often they rise at gradients that deter a fish exhausted from a long migration. There are also the problems of whether the reservoir has destroyed, through siltation in its inflows, the gravelly spawning habitats that many salmonids require. Simply dumping gravel is only a palliative for the river will re-cover them with silt if flows have been reduced. Return of the fish downstream is a bigger problem, for a plunge over a dam many metres high will kill most. Migratory fish runs have in general been destroyed by reservoir construction and beyond removing the dam there is little here that can be restored without human transfer of fish both ways across the obstruction.

All in all, the Water Framework Directive concept of good ecological potential for reservoirs was a brave one but probably doomed from the outset. The problems of eutrophication can be dealt with and are no different from those of natural lakes but the issues of structure and connectivity are much more intractable. Unless they are very large in area so that abstraction leads only to small and gradual changes in water level, there is little that can be done to make reservoirs have the characteristics of natural lakes. Most are built in places where narrow dams pond back large amounts of water for reasons of cost-efficiency and minimising difficulties with land acquisition. The best that can be done is in amenity rather than ecological terms. Tree planting can screen the edges; paths and roads 
around them, designed for access, can be made of materials sympathetic to the local environment. Often they have been of intrusive white concrete when they need only be of hard core crushed local rock. Legislation exists at least in North America that requires continual justification for the existence of dams and weirs. Many may no longer be needed and could be removed. A classic case in the UK is the conversion of the Barn Elms Reservoirs in London to a wetland nature reserve (Yallop \& O'Connell, 2000). These reservoirs were essentially large concrete tanks set on land to which water was pumped for storage rather than the barrage reservoirs mostly discussed here but the principle of removal of what is not essential is a good one.

\section{Conclusion}

I took my title from William Shakespeare's Sonnet LXIV:

$$
\begin{aligned}
& \text { When I have seen by Time's fell hand defaced } \\
& \text { The rich, proud cost of outworn buried age; } \\
& \text { When sometimes lofty towers I see down-razed, } \\
& \text { And brass eternal slave to mortal rage; } \\
& \text { When I have seen the hungry ocean gain } \\
& \text { Advantage on the kingdom of the shore, } \\
& \text { And the firm soil win of the watery main, } \\
& \text { Increasing store with loss and loss with store; } \\
& \text { When I have seen such interchange of state, } \\
& \text { Or state itself confounded to decay, } \\
& \text { Ruin hath taught me thus to ruminate, } \\
& \text { That time will come and take my love away. } \\
& \text { This thought is as a death, which cannot choose } \\
& \text { But weep that which it fears to lose.' }
\end{aligned}
$$

The use of the analogy is appropriate for Shakespeare was noting the ravages of time and human prejudice in destroying what is precious (he was writing at a time when the religious strife of the Reformation in England was leading to the dismantling of a precious artistic heritage, including the ripping out of brass monuments (Rowse, 1984)). His observations of the changing states of land and water, as manifested then and now by the sea are pertinent at the edges of reservoirs. In the past few hundred years we have assumed that we can alter our environment at will, without consequence. As our populations have increased this has been necessary where reasonable comfort, acceptable health and civilised survival have been concerned. But we have assumed that such alterations should serve excesses beyond our needs and we are learning through increasing climatic chaos that there are penalties to be paid for this. We might make a deposit on the payments by critically looking at how many of our water management structures are really needed for civilised survival and look to removing a significant number as we are forced to compromise our excesses with the absolute requirement of maintaining the integrity of natural systems. It is clearly very difficult to increase the ecological value of reservoirs, once constructed, given their purpose. A pragmatic approach might be to restore nutrient parsimony, which is conceptually easy, and as much as possible of biological structure and connectivity despite the absence of a functional littoral zone and the complete destruction of a natural hydrological regime. In the final analysis the concept of increasing ecological potential in reservoirs was well-intentioned but much improvement is unlikely. Perhaps the best approach to achieving good ecological potential in reservoirs is to return good ecological quality to the rivers that have been damaged by them.

Much more care needs also to be taken in deciding to build new dams and reservoirs. Dam building reached a peak in the 1970s but there will be increased pressures for water storage as climate warms in the forthcoming century. If water is to become scarcer in summer in the north temperate world as a result of global warming, the least damaging solutions are mechanisms that promote parsimony of use rather than response always to continued demand.

\section{Acknowledgements}

Support was provided by the EU Framework 6 Project, EUROLIMPACS (GOCE-CT-2003-505540). I am grateful to two anonymous referees for their helpful comments. 


\section{References}

Andrews, E.D. (1986). Downstream effects of Flaming Gorge Reservoir on the Green River, Colorado and Utah. Geological Society of America Bulletin 97, 1012-1023.

Barker, T. (2006). Patterns in space and time. Changes in the limnology of an interconnected lake system. $\mathrm{PhD}$ thesis, University of Liverpool, UK (unpublished).

Baxter, R.M. (1977). Environmental effects of dams and impoundments. Annual Review of Ecology \& Systematics 8, 255-283.

Bednarck, A. (2001). Undamming rivers: a review of the ecological impacts of dam removal. Environmental Management 27, 803-814.

Beschta, R.L. \& Ripple, W.J. (2006). River channel dynamics following extirpation of wolves in northwestern Yellowstone National Park, USA. Earth Surface Processes and Landforms 31, 1525-1539.

Bolding, B., Bonar, S. \& Divens, M. (2004). Use of artificial structure to enhance angler benefits in lakes, ponds and reservoirs: a literature review. Reviews in Fisheries Science 12, 75-96.

Brown, A.M. (1986). Modifying reservoir fish habitat with artificial structures. In: Reservoir Fisheries Management: strategies for the 80s (eds G.E. Hall \& M.J. Van den Avyle), pp. 98-102. Bethesda Md, Fisheries Society, Southern Division, Reservoir Committee.

Calman, R.J., Bilbo, R.E., Schindler D.E. \& Belfield, J.M. (2002). Pacific salmon, nutrients and the dynamics of freshwater ecosystems. Ecosystems 5, 399-417.

Carpenter, S.R., Kitchell, J.F. \& Hodgson, J.R. (1985). Cascading trophic interactions and lake ecosystem productivity. BioScience $35,635-639$.

Cederholm, C.J., Kunze, M.D., Murota, T. \& Sabatini, A. (1999). Pacific salmon carcasses: essential contributions of nutrients and energy for aquatic and terrestrial ecosystems. Fisheries 24, 6-15.

Cole, J.J., Caraco, N.F., Kling, G.W. \& Kratz, T.K. (1994). Carbon dioxide supersaturation at the surface waters of lakes. Science 265, 1568-1570.

Cooke, G.D., Welch, E.B., Peterson, S. \& Nichols, S.A. (2004). Restoration and Management of Lakes and Reservoirs. Third edition. CRC Press, New York. 616 pp.

Cronin, G., Lewis, W.M. \& Schieser, M.A. (2006). Influence of freshwater macrophytes on the littoral ecosystem structure and function of a young Colorado reservoir. Aquatic Botany 85, 37-43.

Davis, S.M. \& Ogden, J.C. (1994). Everglades: The Ecosystem and its
Restoration. St Lucie Press, Gainsville Fla, USA. 826 pp.

del Giorgio, P.A. \& Peters, R.H. (1994). Patterns in planktonic P:R ratios in lakes: influence of lake trophy and dissolved organic carbon. Limnology \& Oceanography 39, 772-787.

del Giorgio, P.A., Cole, J.J. \& Cimberlis, A. (1997). Respiration rates in bacteria exceed phytoplankton production in unproductive systems. Nature 385, 148-151.

Duncan, A. (1990). A review: limnological management and biomanipulation in the London reservoirs. Hydrobiologia 200/201, 541-548.

European Commission (2000). Directive 2000/60/EC, Establishing a framework for community action in the field of water policy. Official Journal of the European Communities L 327, 1-71. European Commission, Brussels.

Findlay, D.L., Vanni, M.J., Paterson, M., Mills, K.H., Kasian, S.E.M., Findlay, W.J. \& Salki, A.G. (2005). Dynamics of a boreal lake ecosystem during a long-term manipulation of top predators. Ecosystems 8, 603-618.

Furey, P.C., Nordin, R.N. \& Mazumder, A. (2004). Water level drawdown affects physical and biogeochemical properties of littoral sediments of a reservoir and a natural lake. Lake $\mathcal{E}$ Reservoir Management 20, 280-295.

Hanson, P.C., Pollard, A.I., Bade, D.L., Predick, K., Carpenter, S.R. \& Foley, J.A. (2004). A model of carbon evasion and sedimentation in temperate lakes. Global Change Biology 10, 1285-1298.

Hansson, L.A. (1996). Algal recruitment from lake sediments in relation to grazing, sinking and dominance patterns in the phytoplankton. Limnology \& Oceanography 41, 1312-1323.

Harmon, M.E., Franklin, J.F., Swanson, F.I., Sollins, P., Gregory, S.V., Lattin, J.D., Anderson, N.H., Cline, S.P., Aumen, N.G., Sedell, J.R., Lienkaemper, G.W., Cromak, J. \& Cummins, K.W. (1986). Ecology of coarse woody debris in temperate ecosystems. Advances in Ecological Research 15, 133-302.

Havel, J.E., Lee, C.E. \& Van der Zanden, M. (2005). Do reservoirs facilitate invasions into landscapes? BioScience 55, 518-525.

Helfield, J.M. \& Naiman, R.J. (2006). Keystone interactions: salmon and bear in riparian forests of Alaska. Ecosystems 9, 167-180.

Hrbacek, J., Dvorakova, M., Korinek, V. \& Prochazkova, L. (1961). Demonstration of the effect of the fish stock on the species composition of zooplankton and the intensity of metabolism of the whole plankton association. Verhandlungen der Internationalen Vereinigung fur theoretische und angewandte 
Limnologie 14, 192-195.

Hutchinson, G.E. (1965). The Ecological Theatre and the Evolutionary Play. Yale University Press, New Haven, Conn. USA. 164 pp.

Hutchinson, G.E. (1975). A Treatise on Limnology. Vol 3. Limnological Botany. Wiley, New York, USA. 660 pp.

Hynes, H.B.N. (1979). The Ecology of Running Waters. Liverpool University Press, Liverpool, UK. 555 pp.

Jeppesen, E., Sondergaard, M, Sondergaard, M \& Christofferson, K (eds). (1998). The Structuring Role of Submerged Macrophytes in Lakes. Ecological Studies 131. Springer, New York, USA. 423 pp. Johnson, S.E. \& Graber, B.E. (2002). Enlisting the social sciences in decisions about dam removal. BioScience 52, 731-738.

Jones, J.I., Eaton, J.W. \& Hardwick, K. (2000). The influence of periphyton on boundary layer conditions: a $\mathrm{pH}$ microelectrode investigation. Aquatic Botany 67, 191-206.

Jonsson, A., Meili, M., Bergstrom, A.-K. \& Jansson, M. (2001). Whole-lake mineralization of allochthonous and autochthonous organic carbon in a large humic lake (Örtrasket, N. Sweden). Limnology \& Oceanography 46, 1691-1700.

Krokhin, E.M. (1975). Transport of nutrients by salmon migrating from the sea into lakes. In: Coupling of Land and Water Systems (ed. A.D. Hasler) pp. 153-156. Springer Verlag, New York, USA.

Lewis, D.M., Elliott, J.A., Lambert, M.F. \& Reynolds, C.S. (2002). The simulation of an Australian reservoir using a phytoplankton community model: PROTECH. Ecological Modelling 150, 107-116.

Ligon, F.K., Dietrich, W.E., \& Trush, W.J. (1995). Downstream ecological effects of dams. BioScience 43, 183-192.

Lund, J.W.G. (1964). Primary production and periodicity of phytoplankton. Verhandlungen der Internationalen Vereinigung fur theoretische und angewandte Limnologie 15, 37-56.

McCarthy, T.S., Ellery, W.N. \& Bloem, A. (1998). Some observations on the geomorphological impact of hippopotamus (Hippopotamus amphibious L.) in the Okavango Delta, Botswana. African Journal of Ecology 36, 44-56.

Meerhoff, M., Iglesias, C., de Mello, F.T., Clemente, J.M., Jensen, E., Lauridsen, T.L. \& Jeppesen, E. (2007). Effects of habitat complexity on community structure and predator avoidance behaviour of littoral zooplankton in temperate versus subtropical shallow lakes. Freshwater Biology 52, 1009-1021.

Moss, B. (1995). The microwaterscape - a four-dimensional view of interactions among water chemistry, phytoplankton, periphyton, macrophytes, animals and ourselves. Water Science E Technology 32, 105-116.

Moss, B. (2007). Shallow lakes, the water framework directive and life. What should it all be about? Hydrobiologia 584, 381-394.

Moss, B., Stephen, D., Balayla, D.M., Becares, E., Collings, S.E., Fernandez-Alaez, C., Fernandez-Alaez, M., Ferriol, C., Garcia, P., Goma, J., Gyllstrom, M., Hansson, L.-A., Hietala, J., Kairesalo, T., Miracle, M.R., Romo, S., Rueda, J., Russell, V., Stahl-Delbanco, A., Svensson, M., Vakkilainen, K., Valentin, M., Van de Bund, W., Van Donk, E., Vicente, E. \& Villena, M.G. (2004). Continental-scale patterns of nutrient and fish effects on shallow lakes: synthesis of a pan-European mesocosm experiment. Freshwater Biology 49, 1633-1649.

O'Sullivan, P.E. \& Reynolds, C.S. (eds) (2003). The Lakes Handbook, Volume 1. Blackwell, Oxford. 699 pp.

Perrin, C.J., Rosenau, M.L., Stables, T.B. \& Ashley, K.I. (2006). Restoration of a montane reservoir fishery via biomanipulation and nutrient addition. North American Journal of Fisheries Management 26, 391-407.

Petts, G.E. (1980). Long term consequences of upstream impoundment. Environmental Conservation 7, 325-332.

Power, M.E., Dietrich, W.E. \& Finlay, J.C. (1996). Dams and downstream aquatic biodiversity: potential food web consequences of hydrologic and geomorphological change. Environmental Management 20, 887-895.

Prince, E.D. \& Maugham, O.E. (1978). Freshwater artificial reefs: biology and economics. Fisheries 3, 5-9.

Reynolds, C.S., Wiseman, S.W. \& Clarke, M.J.O. (1984). Growthrate and loss rate responses of phytoplankton to intermittent artificial mixing and their potential application to the control of planktonic algal biomass. Journal of Applied Ecology 21, 11-39.

Ripple, W.J. \& Beschta, R.I. (2004a). Wolves, elk, willows, and trophic cascades in the upper Gallantin Range of South-western Montana, USA. Forest Ecology and Management 200, 161-181.

Ripple, W.J. \& Beschta, R.L. (2004b). Wolves and the ecology of fear: can predation risk structure ecosystems? BioScience 54, 755-766.

Roni, P., Hanson, K., Beechie, T., Press, G., Pollock, M. \& Bartley, D.M. (2005). Habitat rehabilitation for inland fisheries. Global review of effectiveness and guidance for rehabilitation of freshwater ecosystems. FAO Fisheries Technical Paper 484, 1-116.

Rowse, A.L. (1984). Shakespeare's Sonnets. Third Edition. Macmillan, London, UK. 337 pp. 
Strakosh, T.R., Eitzmann, J.L., Gido, K.B. \& Guy, C.S. (2005). The response of water willow (Justicia americana) to different water inundation and desiccation regimes. North American Journal of Fisheries Management 25, 1476-1485.

Terborgh, J., Lopez, L., Nunez, V.P., Rao, M., Shahabuddin, G., Orijuela, G., Riveros, M., Ascanio, R., Adler, G.H., Lambert, T.D. \& Balbas, L. (2001). Ecological meltdown in predator-free forest fragments. Science 294, 1923-1926.

Terborgh, J., Feeley, K., Silman, M., Nunez, P. \& Balukjian, B. (2006). Vegetation dynamics of predator-free land-bridge islands. Journal of Ecology 94, 253-263.

Timms, R.M. \& Moss, B. (1984). Prevention of growth of potentially dense phytoplankton populations by zooplankton grazing in the presence of zooplanktivorous fish, in a shallow wetland ecosystem. Limnology \& Oceanography 29, 472-486.

Van Donk, E. (2005). Planktonic interactions: development and perspectives. Verhandlungen der Internationalen Vereinigung fur theoretische und angewandte Limnologie 29, 61-72.

Warren, P. (1994). Making connections in food webs. Trends in Ecology and Evolution 9, 136-141.

Wills, T.C., Bremigan, M.T. \& Hayes, D.B. (2004). Variable effects of habitat enhancement structures across species and habitats in Michigan reservoirs. Transactions of the American Fisheries Society 133, 399-411.

World Commission on Dams (2000). Dams and Development. Earthscan Publications, London, UK. 448 pp.

Yallop, M.L. \& O'Connell, M. (2000). Wetland creation: early stages in colonization of phytoplankton and submerged macrophytes in hypereutrophic freshwater lagoons. Aquatic Conservation: Marine and Freshwater Ecosystems 10, 305-309.

\section{Author Profile}

Fresh waters have always been a major part of Brian's life, since learning about the dramatic story of how lakes stratify in his undergraduate career nearly half a century ago, and the stimulation of visiting, as a postgraduate, the enormously friendly FBA laboratory on Windermere. Thereafter he has carried out freshwater research in Africa, the United States and Europe and has taught freshwater science on almost all the continents. The work has involved many approaches, from field observations to experiments in the lab, in mesocosms, experimental tanks and whole lakes and has centred on eutrophication, lake restoration and the effects of climate change. He is presently Holbrook Gaskell Professor of Botany at the University of Liverpool, UK and President of the International Society for Limnology. When he is not happily getting wet and muddy, he plays the double bass and writes poems. 